\title{
Research on the status of chemical pesticide uses in agricultural activities in Phan Me commune, Phu Luong district, Thai Nguyen province
}

\author{
Nghiên cứu thực trạng sủ dụng thuốc bảo vệ thực vật trong sản xuất nông \\ nghiệp trên địa bàn xã Phấn Mễ, huyện Phú Luơng, tỉnh Thái Nguyên
}

Research article

Nguyen, Thi Hue*; Ha, Dinh Nghiem

Faculty of Environment, Thai Nguyen University of Agriculture and Forestry, Quyet Thang, Thai Nguyen, Vietnam

\begin{abstract}
Phan $\mathrm{Me}$ is a midland-mountainous commune of Phu Luong district, Thai Nguyen province, Vietnam where the agricultural activities are predominant occupation. The investigation on the use of plant protection products in here showed that chemical pesticides have been commonly used in agricultural activities. Although some local people have a good attitude in using plant protection products, the status of using chemical pesticides that were not recommended (like Vofatox) has been quite popular due to the old cultivation customs. The local people have not applied any measures for wastewater treatment, or plant protection product package treatment. Besides, the use of plant protection products in higher concentration than recommendation for vegetables or crops caused the residues of toxics in agricultural products as well as in cultivation soil. The accumulation of toxic residues in the environment is a serious matter of concern because of their significant impact on the environment, agricultural ecosystem and human health.
\end{abstract}

Phấn Mễ là một xã trung du miền núi của huyện Phú Luong, tỉnh Thái Nguyên, Việt Nam với hoạt động sản xuất nông nghiệp là chủ yếu. Qua thực tế điều tra tình hình sủ dụng thuốc bảo vệ thực vật (BVTV) tại đây cho thấy hầu hết các loại hình sản xuất nông nghiệp đều sử dụng thuốc BVTV. Một số người dân đã có ý thức trong việc sử dụng thuốc BVTV tuy nhiên do tập quán canh tác tù lâu đời nên việc sủ dụng các loại thuốc bị khuyến cáo, chăng hạn nhu Vofatox, vẫn còn khá phổ biến. Người dân chua tiến hành các biện pháp để xủ lý nuớc thải, bao bì, vỏ chai thuốc BVTV sau khi sủ dụng. Bên canh đó, ho còn sủ dụng thuốc BVTV không đúng liều luợng cho một số loại cây rau để lại du lượng thuốc trên nông sản cũng nhu đất canh tác. Sự tích lũy du lương của nhũng chất độc hại này trong môi truờng là vấn đề đáng lo ngại do sụ ảnh hưởng nghiêm trọng của chúng đối với môi trường sống, hệ sinh thái nông nghiệp và súc khỏe con người.

Keywords: plant protection, agriculture, accumulated toxins, pesticide, environment, ecosystems

\section{Introduction}

Nowadays pesticides have been used popularly to control the diseases and pests whenever they appear in plants and crops. Using pesticides under right instruction as well as technical procedure will bring a good effect in plant protection. In some cases, it is the sole solution due to the fast eradication, easy use, high efficiency in anywhere and anytime and the convenience in buying or exchanging from the local stores. With these advantages, chemical pesticides seem to be the best cure for crops whenever diseases appear and they have been used by farmers themselves in a large quantity. The use of chemical pesticides brings the efficiency in controlling pest and diseases for crops, but it also causes the unpredictably serious consequences for plants and human health. Even it may lead to phenomenon of "un-controlling", so that pests and diseases may widespread in large areas with much more serious consequences such as environmental pollution, adverse effect on the health of consumers and 
producers as well as disruption of the agricultural ecosystem (Nguyen, 2007). The scope of the paper is to present the results of research on the status of using chemical pesticide in agricultural activities in Phan $\mathrm{Me}$ commune, Phu Luong district, Thai Nguyen province.

\section{Material and methods}

\subsection{Materials}

Research materials are the issues related to plant protection products (chemical pesticides) and agricultural activities of farmers in Phan Me commune - Phu Luong District - Thai Nguyen province - Vietnam.

The survey with 100 questionnaires was designed to get information from local agricultural households.

\subsection{Methods}

Primary data and documents on natural resources and eco-social conditions were collected and then analyzed statistically by using Microsoft Office (Excel) software. The agricultural households and stores selling the agricultural products in studied areas were chosen randomly.
Based on soil conditions, terrain and farming systems in the Phan Me commune, studied areas were divided into 3 locations: First location was on the west of the commune where forestry, tea and fruit plants were abundant. Second location was the center of the commune, where annual crops were mainly cultivated. The third location was the east of the commune with many different kinds of crops.

\section{Results and discussion}

\subsection{The situation of using chemical pesticide in agricultural activities in Phan Me commune}

The crops were controlled by spraying with chemical pesticides regularly from 7-10 days/times. The number of chemical pesticides spraying for rice plants is the highest with 6 times per one cultivation crop. The different types of chemical pesticides were used depending on pest species. It is realized that the chemical pesticide named "Vofatox" that was banned by the government still has been using by farmers, and it is hardly used with biological pesticides. This caused environmental impacts, especially in water and land environment.

Table 1. Status of using chemical pesticide in agriculture in Phan Me commune

\begin{tabular}{|c|c|c|c|c|c|c|}
\hline No. & Crops & $\begin{array}{c}\text { Number of } \\
\text { sprays / } \\
\text { crop }\end{array}$ & $\begin{array}{c}\text { Periodic } \\
\text { spraying (days / } \\
\text { times) }\end{array}$ & Chemical pesticides & $\begin{array}{c}\text { Isolation } \\
\text { time (days) }\end{array}$ & $\begin{array}{c}\text { Harvest } \\
\text { time/crop } \\
\text { (weeks) }\end{array}$ \\
\hline 1 & Rice plants & 6 & 10 & $\begin{array}{l}\text { Bassa50SD } \\
\text { Sattrungdan95BTN } \\
\text { Rigell 80WG } \\
\text { Sofit 300EC } \\
\text { Ferim 18,5WP } \\
\text { Baran 50EC }\end{array}$ & 15 & 12 \\
\hline 2 & Vegetables & 2 & 15 & $\begin{array}{l}\text { Ridomil } 68 \text { WP } \\
\text { Vofatox }\end{array}$ & 14 & 6 \\
\hline 3 & Corn, peanut & 4 & 12 & Baran 50EC & 7 & 12 \\
\hline 4 & Fabrics, label & 5 & 10 & $\begin{array}{l}\text { Reasgant 1.8EC, 2WG, } \\
3.6 \mathrm{EC}, 5 \mathrm{EC}, 5 \mathrm{WG}, \text { Butan } \\
60 \mathrm{EC}\end{array}$ & 15 & 15 \\
\hline 5 & Tea plants & 3 & 7 & $\begin{array}{l}\text { Genol 0.3DD,1.2DD } \\
\text { Actara 25WG,350FS }\end{array}$ & 7 & 5 \\
\hline
\end{tabular}

\subsection{The status of chemical pesticide use on crops and recommendation}

pesticides are even over used widely. Most crops are sprayed at least 1 time/crop, especially 2-3 times /crop for vegetables.

The results of investigation on use of plant protection products in agricultural activities showed that chemical

Table 2. The amount of pesticides and practical recommendations on plant

\begin{tabular}{|c|c|c|c|c|c|}
\hline \multirow{3}{*}{ Crops } & \multirow{3}{*}{ Chemical Pesticides } & \multicolumn{2}{|c|}{ Farmer uses } & \multicolumn{2}{|c|}{ Recommendation } \\
\hline & & Dosage & Isolation & Dosage & Isolation \\
\hline & & (Kg/ha/time) & (Date) & (Kg/ha/time) & (Date) \\
\hline \multirow[t]{4}{*}{ Rice } & Bassa50SD & 0.75 & 10 & 0.8 & 14 \\
\hline & Sattrungdan 95BTN & 0.8 & 8 & $0.60-0.83$ & 15 \\
\hline & Delfin WG & 0.5 & 4 & $0.60-0.70$ & 1 \\
\hline & Sotoxo 3SC & 0.5 & 15 & $0.5-0.8$ & - \\
\hline
\end{tabular}




\begin{tabular}{|c|c|c|c|c|c|}
\hline \multirow{3}{*}{ Crops } & \multirow{3}{*}{ Chemical Pesticides } & \multicolumn{2}{|c|}{ Farmer uses } & \multicolumn{2}{|c|}{ Recommendation } \\
\hline & & Dosage & Isolation & Dosage & Isolation \\
\hline & & (Kg/ha/time) & (Date) & (Kg/ha/time) & (Date) \\
\hline & Rigell 80WG & 0.1 & 10 & 0.03 & 14 \\
\hline & Neptoxin 95WG & 0.5 & 10 & $0.5-0.75$ & 14 \\
\hline \multirow[t]{5}{*}{ Vegetables } & Baran 50EC & 0.2 & 5 & $0.08-0.17$ & 7 \\
\hline & Vofatox & 0.5 & 10 & - & - \\
\hline & Ridomil 68 WP & 1.2 & 7 & $0.8-1.3$ & 7 \\
\hline & Anvil 5SC & 0.9 & 10 & $0.5-1$ & 14 \\
\hline & Dacomil 75WP & 0.5 & 7 & $0.6-0.8$ & 10 \\
\hline Corn, peanuts & Baran 50EC & 0.5 & 7 & $0.3-0.6$ & 7 \\
\hline \multirow[t]{2}{*}{$\begin{array}{l}\text { Fruit trees } \\
(\text { fabric, label ...) }\end{array}$} & $\begin{array}{l}\text { Reasgant 1.8EC, } 2 \mathrm{WG}, \\
3.6 \mathrm{EC}, 5 \mathrm{EC}, 5 \mathrm{WG}\end{array}$ & 0.6 & 30 & $\begin{array}{l}0.15-0.5 \text { (li- } \\
\text { ter/ha) }\end{array}$ & 15 \\
\hline & $\begin{array}{l}\text { Ketomium } 1.5 \quad \mathrm{x} \\
1000000 \mathrm{cfu} / \mathrm{g}\end{array}$ & - & - & - & - \\
\hline \multirow[t]{2}{*}{ Tea } & Actara $25 \mathrm{WG}, 350 \mathrm{FS}$ & 0.1 & 10 & $0.03-0.08$ & 5 \\
\hline & Genol 0.3DD,1.2DD & 0.8 & 10 & $\begin{array}{l}0.6-0.8(\mathrm{li}- \\
\text { ter/ha) }\end{array}$ & 7 \\
\hline
\end{tabular}

\subsection{The way of spraying chemical pesticides of farmers}

The way of spraying pesticides plays a very important role in controlling pests and diseases for crops. The knowledge on selecting the time of spraying based on the weather and wind direction of farmers in Phan $\mathrm{Me}$ is shown in Table 3.
All farmers who participated in the answering to the questionaire in Phan Me commune usually sprayed pesticides in cool weather, downwind conditions. These were the suitable conditions that reduced the influence of chemical pesticides to user's health, improved the efficiency of pesticides. However, there were $80 \%$ of the households surveyed have fully understanding of this knowledge. Thus farmers need to improve more knowledge on using pesticides properly in order to efficiently protect environment and human health.

Table 3. Time selection based on the weather and wind direction when spraying pesticides (100 questionaires)

\begin{tabular}{clcccc}
\hline \multirow{2}{*}{ No. } & \multirow{2}{*}{ Content } & Survey results (number of farmers) & \multicolumn{2}{c}{ Rate (\%) } \\
\cline { 3 - 6 } & & Yes & No & Yes & No \\
\hline 1 & Sparaying in good weather, cool, no sunny & 100 & 0 & 100 & 0 \\
2 & Backward Spraying & 60 & 40 & 60 & 40 \\
3 & Downwind Spraying & 100 & 0 & 100 & 0 \\
4 & Full understanding of Spraying & 80 & 20 & 80 & 20 \\
\hline
\end{tabular}

Some farmers were aware of the impact of pesticides. Therefore, when mixing and spraying chemical pesticides they equipped themselves with protection clothes, masks and gloves. However, others are not interested in use of these safety working closings. Most of the people answered that they were difficult to use. The frequency of use of protective equipment is shown in Table 4.

Table 4. The situation of using protection equipment when spraying chemical pesticides in Phan Me commune

\begin{tabular}{clcc}
\hline \multirow{2}{*}{ No. } & \multirow{2}{*}{ Villages } & \multicolumn{2}{c}{ Using protective equipment when spraying chemical pesticides } \\
\cline { 3 - 4 } & My Khanh & Yes $(\mathbf{\%})$ & No (\%) \\
\hline 1 & Lang Tro & 75 & 25 \\
2 & Gia 2 & 100 & 0 \\
3 & Bau 2 & 77.78 & 22.22 \\
4 & Tan Hoa & 100 & 0 \\
5 & Phu Son & 75 & 25 \\
6 & Hoa 2 & 80 & 20 \\
7 & Lan 1 & 66.67 & 33.33 \\
8 & Bo 1 & 75 & 25 \\
9 & & 80 & 20 \\
\hline
\end{tabular}

In two villages Lang Tro and Bau 2 of Phan Me commnue, $100 \%$ of the surveyed households were fully equipped with protection wearing when spraying chemical pesticides. In the others such as Gia 2, Tan Hoa, Lan 1, My Khanh, Phu Son and Hoa 2, from 66.67\% to $80 \%$ of surveyed households were equipped with safety 
working closings when spraying pesticides. From $20 \%$ to $33.33 \%$ of the households were not equipped. This affected directly the health of who sprayed chemical pesticides.
The situation of waste collection, storage and treatment was as follows:

- Solid waste:

The result of our survey on use and disposal of waste after spraying pesticides by farmers are shown in Table 5 .

Table 5. The using and disposing of pesticide waste from farmers

\begin{tabular}{clcccc}
\hline \multirow{2}{*}{ No. } & \multirow{2}{*}{ Villages } & \multicolumn{2}{c}{$\begin{array}{c}\text { Using river water, canal water to } \\
\text { wash spray }\end{array}$} & $\begin{array}{c}\text { Collection of package, pesticide bottle } \\
\text { after using }\end{array}$ \\
\cline { 3 - 6 } & & Yes (\%) & No (\%) & Yes (\%) & No (\%) \\
\hline 1 & My Khanh & 100 & 0 & 75 & 25 \\
2 & Lang Tro & 75 & 25 & 100 & 0 \\
3 & Gia 2 & 88.89 & 11.11 & 100 & 0 \\
4 & Bau 2 & 75 & 25 & 75 & 25 \\
5 & Tan Hoa & 100 & 0 & 100 & 20 \\
6 & Phu Son & 100 & 0 & 80 & 16.67 \\
7 & Hoa 2 & 83.33 & 16.67 & 83.33 & 0 \\
8 & Lan 1 & 75 & 25 & 100 & 10 \\
9 & Bo 1 & 100 & 0 & 90 & \\
\hline
\end{tabular}

Local farmers had the habits of using river and canal water to wash sprayers directly. The packings of pesticide were burned or thrown at the field. And the bottles of pesticide were sold or reused for other purposes. Many pesticide packages and bottles which were not treated properly were found in some villages such as My Khanh, Bau 2, Phu Son and Hoa 2. However, in the other villages such as Lang Tro, Gia 2, Tan Hoa and Lan 1, 100\% of the surveyed households collected packages, pesticide bottles after using. Thus, there was still an uncontrollable number of packages and bottles of pesticides that contained potential harmful effect on environmental quality.

- Wastewater

Wastewater caused by cleaning and washing process after spraying may contain high concentration of pesticides. However, this water source was not collected but discharged directly into rivers near the field by $100 \%$ interviewed households.

\section{Conclusions}

- Pesticides that were used largely in Phan Me commune include 19 types mainly originated from chemicals. Biological products were rarely used. Pesticides named "Vofatox" was prohibited but still used by the local farmers.
- Many farmers accounting for 10\% - 25\% did not have measures for treatment of sewage, packages and bottles after using pesticide.

- There were from $66.67 \%$ to $80 \%$ of surveyed households equipped with protective clothes when spraying pesticides. The others who did not equip were in the danger of being affected by toxic compounds from pesticides.

- Some chemical pesticides named Rigell 80W, Baran 50EC, Vofatox, Ridomil $68 \mathrm{WP}$, which were used with incorrect dosage and not following the instructions for some crops, such as vegetables, beans might leave residues on agricultural products and cultivation soil. The accumulation of toxins in the environment is a matter of concern about the future impact on the environment, agriculture and ecosystem as well as human health.

\section{References}

[1] Le Huy Ba (2002), Environmental Toxicology, National University publisher, Ho Chi Minh City.

[2] Ministry of Agriculture \& Rural Development (2010), The list of drugs is permitted, restricted and banned from use in Vietnam, the Circular of Ministry of Agriculture and Rural Development.

[3] Nguyen Tran Oanh (2007), Using pesticides, Agriculture Publisher. 